\title{
CHROMOSOME NUMBERS AND OTHER KARYOLOGICAL DATA OF FOUR STEMONA SPECIES (STEMONACEAE) FROM THAILAND
}

\author{
MARKUS HARTL \& MICHAEL KIEHN \\ Institute of Botany, University of Vienna, Rennweg 14, A-1030 Vienna, Austria \\ e-mail: michael.kiehn@univie.ac.at
}

\begin{abstract}
SUMMARY
Chromosome numbers and other karyological data of four Stemona spp. (Stemonaceae) from Thailand are reported. Three taxa (S. collinsae Craib, S. kerrii Craib and an unidentified species) exhibit $2 \mathrm{n}=14$ chromosomes, for $S$. curtisii Hook.f. a range of $2 \mathrm{n}=13-16$ was established. Based on the counts of c. $30 \%$ of the species of Stemona, $\mathrm{x}=7$ is very likely to be the basic number for the genus. Chromosome size and morphology of the investigated species are compared with literature data and show differences that might be of importance for infrageneric classification. In this connection the taxonomic position of the genus Pentastemona from Sumatra is also discussed.
\end{abstract}

Key words: Pentastemona, Stemona, Stemonaceae, Thailand, chromosome numbers, karyology.

\section{INTRODUCTION}

As for many other tropical plants, cytological information about the small monocotyledonous family Stemonaceae is incomplete. Of the 23 species of its largest genus Stemona (Watson \& Dallwitz, 2000) only three have been investigated so far, all revealing $2 \mathrm{n}=14$ chromosomes (Oginuma et al., 2001). Chromosome counts for members of the two other genera in Stemonaceae s.str. deviate clearly from $\mathrm{x}=7$ (Croomia: $2 \mathrm{n}=24$, Stichoneuron: $2 \mathrm{n}=18$, see survey in Oginuma et al., 2001). Nevertheless, $\mathrm{x}=7$ is suggested as the basis number of the family by Dahlgren et al. (1985) and Oginuma et al. (2001). This number is also found in Pentastemona egregia (Schott) Steenis $(2 \mathrm{n}=14$; Petersen, 1991) of the recently established family Pentastemonaceae, which formerly was part of Stemonaceae (Duyfjes, 1991). Karyomorphological data are only available for four taxa of the family (two Stemona and two Croomia species, Oginuma et al., 2001).

The present paper provides first chromosome data for S. collinsae, S. curtisii, S. kerrii, and for an unidentified (probably new) Stemona species. It discusses the karyological characters of Stemonaceae and taxonomic implications of the chromosome data.

\section{MATERIAL AND METHODS}

Plants were collected during field trips in Thailand by S. Vajrodaya and H. Greger and subsequently cultivated at the Botanical Garden of the University of Vienna (HBV). 
Table 1. Chromosome numbers of four Stemona spp. Abbreviations: $2 \mathrm{n}=$ diploid chromosome number. Investigated plant tissue: a = young anthers before meiosis; ov = young ovaries; ow = ovary wall. Staining: $\mathrm{F}=$ Feulgen-reagent; $\mathrm{G}=$ Giemsa; $\mathrm{AC}=$ aceto-carmine.

\begin{tabular}{|c|c|c|c|c|}
\hline taxon / provenance & code & $2 n$ & tissue & staining \\
\hline $\begin{array}{l}\text { Stemona collinsae Craib } \\
\text { SE Thailand, Si Racha, coastal slopes }\end{array}$ & HG860 & 14 & $\mathrm{a}$ & $\mathrm{G}$ \\
\hline $\begin{array}{l}\text { Stemona curtisii Hook.f. } \\
\text { S Thailand, Narathiwat }\end{array}$ & HG917 & $13-16$ & ov & $\mathrm{G}, \mathrm{F}$ \\
\hline $\begin{array}{l}\text { Stemona kerrii Craib } \\
\text { N Thailand, Huay Di Mi, Mae Rim, Chiang Mai }\end{array}$ & HG885 & 14 & ov, ow & $\mathrm{G}, \mathrm{AC}$ \\
\hline $\begin{array}{l}\text { Stemona spec. } \\
\text { N Thailand, Khao Luang, Sukhothai }\end{array}$ & HG893 & 14 & $\mathrm{a}$ & G \\
\hline
\end{tabular}

Collection data and voucher specimen numbers of the taxa investigated are given in Table 1. Voucher specimens are deposited at WU in the collection of H. Greger.

Young flower buds from cultivated individuals were pretreated in a solution of $0.05 \%$ colchicin ( 24 hours at $4{ }^{\circ} \mathrm{C}$ in the dark), followed by fixation with a fresh mixture of ethanol $(96 \%)$ and glacial acetic acid $(3: 1)$. The fixed material was stored at $4{ }^{\circ} \mathrm{C}$. For chromosome staining Feulgen reagent, Giemsa, or aceto-carmine were used (see Kiehn et al., 1991, for details on staining procedures). Since Feulgen-staining did not provide satisfying results, the preparations were air-dried and afterwards additionally stained with Giemsa or aceto-carmine. Permanent slides for all counts are deposited in the collection of M. Kiehn.

\section{RESULTS AND DISCUSSION}

The results of the investigations are presented in Table 1. Due to the large size of the chromosomes (up to $7.5 \mu \mathrm{m}$ in nearly full contraction, see Table 2) the chromosomes were twisted around each other in the mitotic or meiotic cell divisions. This made chromosome counts rather difficult. Investigation of other plant tissues like root tips and shoot apices may lead to better results as well as the application of other fixation and pretreatment techniques.

\section{Chromosome numbers in Stemona}

A chromosome number of $2 \mathrm{n}=14$ could be established with certainty for three collections representing three different taxa of Stemona, while for S. curtisii only a range of $2 n=13-16$ could be determined. These findings are in accordance with the former literature reports on the genus (see survey in Oginuma et al., 2001); c. 30\% of the Stemona species are counted now. The new data support the assumption of Oginuma et al. (2001), that $x=7$ is the basic number for the whole genus. The uniformity in chromosome numbers is in contrast to differences observed in other character states within the genus, like morphology (Duyfjes, 1993; Tsi \& Duyfjes, 2000), chemistry (Brem et al., 2002; Kaltenegger et al., 2003) and DNA-sequence analysis (Pfosser, unpubl.). These differences seem to support a classification of the genus into subgroups. 
Table 2. Chromosome sizes reported for species of Stemonaceae and of Pentastemona.

\begin{tabular}{lcl}
\hline taxon & chromosome size & literature \\
\hline Croomia heterosepala (Backer) Okuyama & $2.3-4.4 \mu \mathrm{m}$ & Oginuma et al., 2001 \\
Croomia japonica Miq. & $1.7-4.6 \mu \mathrm{m}$ & Oginuma et al., 2001 \\
Croomia pauciflora Torr. ex Torr. \& Gray & $1-1.5 \mu \mathrm{m}$ & Petersen, 1991 \\
Pentastemona egregia (Schott) Steenis & $3-5 \mu \mathrm{m}$ & Petersen, 1991 \\
Stemona collinsae Craib & $2.5-6.5 \mu \mathrm{m}$ & this study \\
Stemona curtisii Hook.f. & $4-6.7 \mu \mathrm{m}$ & this study \\
Stemona japonica Miq. & $2.9-6.3 \mu \mathrm{m}$ & Oginuma et al., 2001 \\
Stemona kerrii Craib & $4.2-7.5 \mu \mathrm{m}$ & this study \\
Stemona sessilifolia Miq. & $2.9-6.3 \mu \mathrm{m}$ & Oginuma et al., 2001 \\
Stichoneuron caudatum Ridl. & $2-4 \mu \mathrm{m}$ & Petersen, 1991 \\
\hline
\end{tabular}

\section{Chromosome size and morphology}

Chromosome sizes reported for Stemonaceae and for the genus Pentastemona are summarized in Table 2. The absolute sizes and the ranges for Stemona species observed by Oginuma et al. (2001) and in the present study are similar. In Stichoneuron and Croomia at least the largest chromosomes are significantly smaller than the chromosomes of the investigated Stemona species. Pentastemona egregia exhibits a larger chromosome size $(3-5 \mu \mathrm{m})$ than any other Stemonaceae except for the members of Stemona itself. Oginuma et al. (2001) report differences between the karyotypes of S. sessilifolia and S. japonica and document two satellites for both species. Two large satellites are also observed in the three taxa of the present study for which exact counts were possible. Chromosome length differences in S. sessilifolia and S. japonica are described as gradual by Oginuma et al. (2001). This also holds true for S. kerrii and for Stemona spec. (HG893) studied here. Stemona collinsae, however, has one pair of chromosomes (c. $2.5 \mu \mathrm{m}$ ) clearly smaller than all other chromosomes. Further karyological studies are required to quantify the observations and to elucidate the importance of observed differences in karyological traits for the infrageneric classification in Stemona.

\section{Relationships between Pentastemona and the genera of Stemonaceae}

The genus Pentastemona was excluded from Stemonaceae and placed in a separate family (Pentastemonaceae) by Duyfjes (1991). Recent molecular studies (Caddick et al., 2000) are opposing this view, they place Pentastemona as the basal clade within Stemonaceae. The Angiosperm Phylogeny Group (APG, 1998; APGII, 2003) also treats Pentastemonaceae as synonym to Stemonaceae. Oginuma et al. (2001) discuss the likelihood of Pentastemona being a (basal) member of the Stemonaceae based on the available molecular, karyological and morphological data. In their view, karyological data do not contradict a placement of the genus Pentastemona in Stemonaceae. In addition to their arguments, also the reported chromosome sizes fit into this picture. More studies of karyotypes are desirable for getting additional insights in the relationships of the Stemonaceae-Pentastemona complex. 


\section{ACKNOWLEDGEMENTS}

We are grateful to S. Vajrodaya, Dept. Botany, Kasetsart University, Bangkok and to H. Greger, Dept. Comparative \& Ecological Phytochemistry, Institute of Botany, University Vienna for collecting and identifying the plant material.

\section{REFERENCES}

APG [= Angiosperm Phylogeny Group]. 1998. An ordinal classification for the families of flowering plants. Ann. Missouri Bot. Gard. 85: 531-553.

APG [= Angiosperm Phylogeny Group] II. 2003. An update of the Angiosperm Phylogeny Group classification for the orders and families of flowering plants: APG II. Bot. J. Linn. Soc. 141: 399-436.

Brem, B., C. Seger, T. Pacher, O. Hofer, S. Vajrodaya \& H. Greger. 2002. Feeding deterrence and contact toxicity of Stemona alkaloids - a source of potent natural insecticides. J. Agric. Food Chem. 50: 6383-6388.

Caddick, L.R., P.J. Rudall, P. Wilkin \& M.W. Chase. 2000. Yams and their allies: systematics of Dioscoreales. In: K.L. Wilson \& D.A. Morrison (eds), Monocots: systematics and evolution: 3-16. CSIRO, Melbourne.

Dahlgren, R.M.T., H.T. Clifford \& P.F. Yeo. 1985. The families of the Monocotyledons: structure, evolution, and taxonomy: 121-123. Springer Verlag, Berlin, New York.

Duyfjes, B.E.E. 1991. Stemonaceae and Pentastemonaceae; with miscellaneous notes on members of both families. Blumea 36: 239-252.

Duyfjes, B.E.E. 1993. Stemonaceae. Flora Malesiana 11: 399-409. Rijksherbarium/Hortus Botanicus, Leiden.

Kaltenegger, E., B. Brem, K. Mereiter, H. Kalchhauser, H. Kählig, O. Hofer, S. Vajrodaya \& H. Greger. 2003. Insecticidal pyrido[1,2-a]azepine alkaloids and related derivatives from Stemona species. Phytochemistry 63: 803-816.

Kiehn, M., E. Vitek, E. Hellmayr, J. Walter, J. Tschenett, C. Justin \& M. Mann. 1991. Beiträge zur Flora von Österreich: Chromosomenzählungen. Verh. Zool.-Bot. Ges. Österreich 128: 19-39.

Oginuma, K., K. Horiuchi \& T. Fukuhura. 2001. Karyomorphology of two genera in Stemonaceae. Acta Phytotax. Geobot. 52: 57-64.

Petersen, G. 1991. In: B.E.E. Duyfjes, Stemonaceae and Pentastemonaceae; with miscellaneous notes on members of both families. Blumea 36: 242.

Tsi, Z.H. \& B.E.E. Duyfjes. 2000. Stemonaceae. In: Z.Y. Wu \& P. Raven (eds), Flora of China, Vol. 24: 70-72. Science Press, Beijing.

Watson, L. \& M.J. Dallwitz. 2000. The families of flowering plants: descriptions, illustrations, identification, and information retrieval. Version: 14th Dec. 2000. http://biodiversity.uno.edu/ delta/angio/www/stemonac.htm. 